\title{
RAPTORIAL BIRDS \\ OF THE U.S.A.E.C. HANFORD RESERVATION, SOUTH-CENTRAL WASHINGTON
}

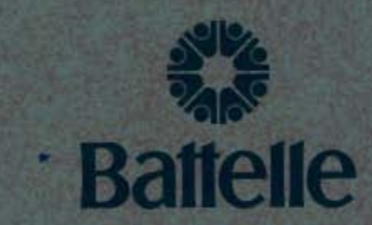

Pacific Northwest Laboratories Richland, Washington 99352

OCTOBER 1973

Prepared for the U.S. Atomic Energy Commission under Contract AT(45-1):1830 


\title{
NOTICE
}

The report was prepared as an account of work sponsored by the United States Government. Neither the United States nor the United States Atomic Energy Commission, nor any of their employees, nor any of their contractors, subcontractors, or their employees, makes any warranty, express or implied, or assumes any legal liability or responsibility for the accuracy, completeness or usefulness of any information, apparatus, product or process disclosed, or represents that its use would not infringe privately owned rights.

\author{
PACIFIC NORTHWEST LABORATORY \\ operated by \\ BATTELLE \\ for the \\ U.S. ATOMIC ENERGY COMMISSION \\ Under Contract AT(45-1)-1830
}

\author{
Printed in the United States of America \\ Available from \\ National Technical Information Service \\ U.S. Department of Commerce \\ 5285 Port Royal Road \\ Springtield, Virginia 22151 \\ Price: Printed Copy \$4.00; Microtiche \$1.45
}

ARC-AL MICMLAND WASO 
BNWL-1790

UC-11, Environmental

and Earth Sciences

\title{
33679000622896
}

\section{RAPTORIAL BIRDS OF THE U.S.A.E.C. HANFORD RESERVATION, SOUTH-CENTRAL WASHINGTON 1}

by

\author{
Richard R. 0lendorff ${ }^{2}$ \\ Field Associate \\ American Museum of Natural History \\ Central Park West at 79th Street \\ New York, New York 10024
}

October 1973

1 This project was supported by the U.S. Atomic Energy Commission under Contract AT(45-1)-1830 with Battelle, Pacific Northwest Laboratories, Consultant Agreement BCA-796.

2present address, 1939 Wyoming Street, Bremerton, Washington, 98310

BATTELLE

PACIFIC NORTHWEST LABORATORIES

RICHLAND, WASHINGTON 99352 
BNWL -1790

\section{PREFACE}

One of the singular features of the Hanford Reservation is the presence of numerous birds of prey. Security restrictions over the last 30 years not only protected the integrity of the project, they also freed these large raptorial birds from harassment. Along with the coyote, the raptorial birds are the most important predators in the area, taking smal1 and medium-sized mammals, birds, reptiles and even insects. Employees in the outer areas have long enjoyed the opportunity to observe these spectacular large birds soaring in a thermal, or raising their young in a low tree close to their work area. Over the years of protection the birds have demonstrated an indifference to humans and almost all of their activities. As a result it is possible to approach and observe the nesting birds far more closely than one could off the reservation.

Several of us observed over the years that the raptorial birds were using trees or structures left by the former residents of Hanford and White Bluffs for nesting sites. Through our association with the National Science Foundation's International Biological Program, Grasslands Biome, we became familiar with the findings of Dr. 0lendorff who was studying birds of prey on the Pawnee National Grassland in Colorado. One of his observations was that man-made structures often provided nesting sites lacking in the treeless parts of the grassland. This positive impact of man's activities was noteworthy and we wished to determine if a similar situation existed on the Hanford Reservation. We also wanted to take advantage of Dr. 0lendorff's expertise in evaluating the status of our raptorial bird populations, the potential of the Reservation for research studies, and the role that the site might play as a national raptor management area.

Dr. 0lendorff was retained as a consultant during fiscal year 1973 as part of the AEC sponsored research programs entitled, "Terrestrial Animal Ecology," and "Grasslands Studies." This report synthesizes his observations and recommendations.

Thomas P. O'Farre11

Senior Research Scientist

Ecosystems Department 
BNWL -1790

\section{ABSTRACT}

Over 50 nesting pairs of raptors were found on the U.S. Atomic Energy Commission's Hanford Reservation in south-central Washington during 17 mandays afield in 1973. The Hanford Reservation was divided into 10 regions which were of varying importance to raptors. The raptor populations of each region were considered in conjunction with the local topography, range conditions, availability of nest sites and prey base (in a superficial way).

The densities of 1 arge raptors in the various regions ranged from no pairs where nest sites were unavailable, to an extrapolated average of 44.4 pairs per 100 square miles near the old towns of Hanford, White Bluffs and East White Bluffs. The dominant nesting species were marsh hawks, Swainson's hawks, red-tailed hawks and great horned owls in about equal numbers. Prairie falcons were numerous in certain areas.

Comparisons with the raptor populations of northeastern Colorado were made. At Hanford the number of raptorial species was less, but the number of pairs of large raptors nesting per unit area (density) was comparable to or greater than on the Pawnee National Grassland and adjacent privately owned land in Colorado.

Recommendations for further studies and management are presented. 
BNWL- 1790

\section{CONTENTS}

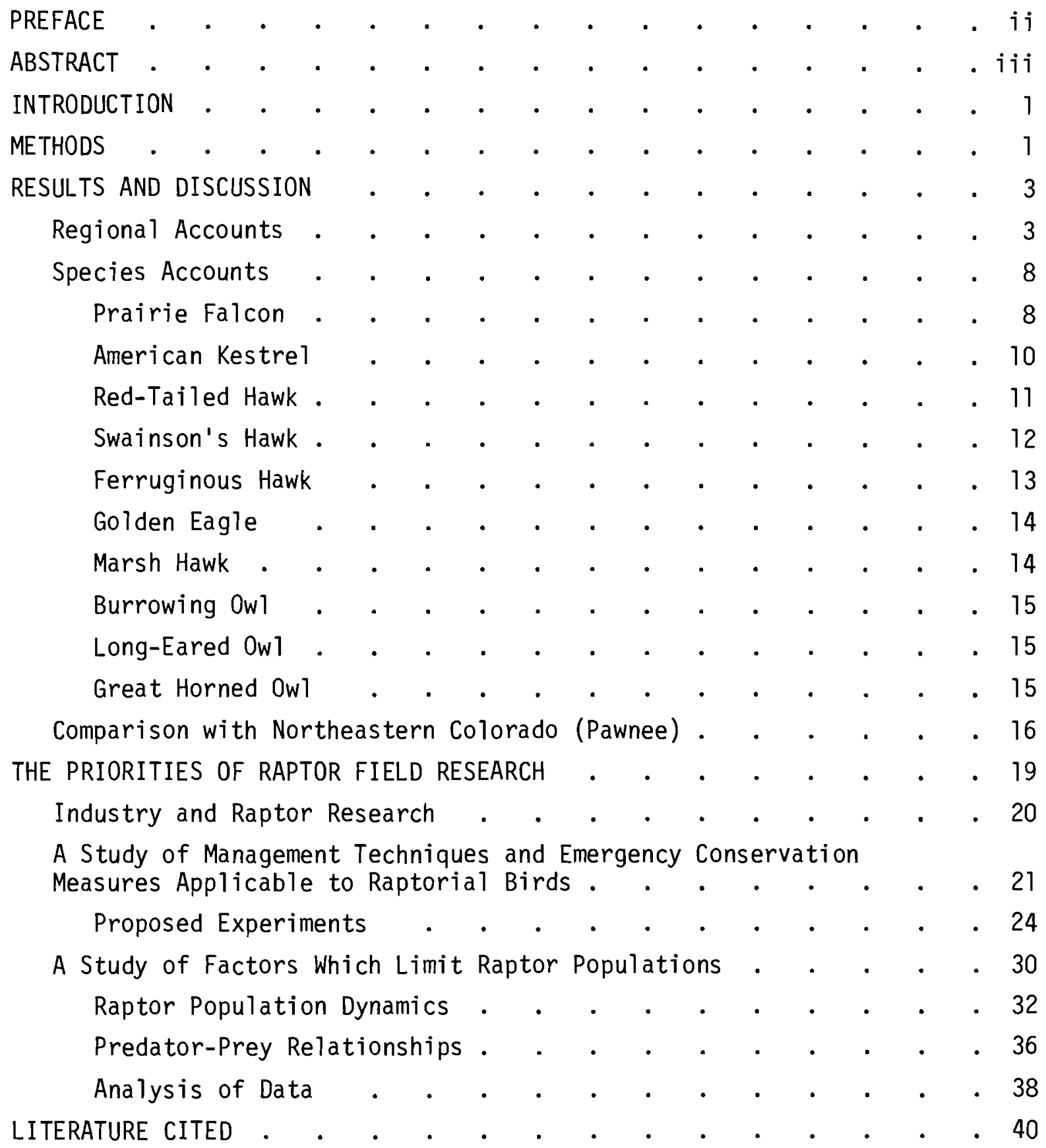


BNWL- 1790

\section{RAPTORIAL BIRDS OF THE U.S.A.E.C. HANFORD RESERVATION, SOUTH-CENTRAL WASHINGTON}

Richard R. 0lendorff

\section{INTRODUCTION}

The following report has been prepared in fulfillment of Consultant Agreement BCA-796 between the author and Battelle Northwest Laboratories as part of Prime Contract AT(45-1)-1830 from the United States Government on behalf of the Atomic Energy Commission. The field work was conducted between 19 February and 11 May 1973 on the Atomic Energy Commission Hanford Reservation in south-central Washington which includes within its boundaries the ALE (Arid Lands Ecology) Reserve and the International Biological Program (IBP), Grassland Biome Site.

This report is the considered opinion of the author and not necessarily is the content based on adequate and complete information. The findings are presented in an "exploded" format--first with regard to land area, then to species, then to comparisons with northeastern Colorado. I have made no attempt to strictly separate results and discussions. This approach is taken because 1) research funds were not available for an adequate and complete study of the area and 2) the personnel at Battelle desired only a quick survey of the raptor populations on which to evaluate the potential for fruitful raptor research--information that would then be used to obtain other funds for more thorough studies on the Hanford Reservation, if warranted. Recommendations for further study are included.

\section{METHODS}

The following days were spent on the Hanford Reservation: 19-20 February, 3-4 and 9-11 Apri1, and 7-11 May 1973. Mr. Stephan B. Layman assisted during the week of May 7. The total number of man-days of "on site" work was approximately 17. Between 65 and 75 percent of the Hanford Reservation south and west of the Columbia River was searched. 
As many of the available roads as possible were driven searching for and checking likely nest sites of large raptors. Promising sites were checked closely on foot or, if possible, by the aid of a variable 15-60X spotting scope. Small raptors such as American kestrels (Falco sparverius) and burrowing owls (Speotyto cunnicularia) were noted only as a result of searches for the larger hawks and falcons. Marsh hawks (Circus cyaneus) were noted only when courting. A thorough search for all small raptors and marsh hawks on the Hanford Reservation would be futile due to the difficulty of locating their nests. On 8 and 9 May the east bank of the Columbia River was checked between Wahluke and the old town of Hanford from a 16-foot aluminum boat powered by a 10-horsepower motor. This allowed very close observation of the cliffs and beaching wherever necessary.

Brief notes were taken in a field notebook but the most valuable record of the work accomplished is a map on which land was shaded section by section as it was searched (Figure 1). All raptor nests were plotted on the same map. In many cases visual contact with every quarter section of land was not possible; the coverage of sections is considered quite accurate, but not 100 percent accurate because of trees possibly hidden by the rolling terrain.

Most of the nests were not climbed due to time limitations, the lack of adequate climbing gear and because most birds were on eggs when the field work was conducted. The latter reason stems from the fact that the incubation period is the most critical time for nest desertions if the birds are unduly disturbed. Thus, in many cases, the dots on the map represent breeding pairs rather than nests found, although the majority of nests were actually located.

It is important to note that many areas were not accessible because of sandy conditions on the back roads, contaminated areas, and restrictions around reactor areas. Although permission probably could have been obtained to visit these areas, the logistics involved would not have been worth the time considering the amount of work to do elsewhere. Other Battelle and Atlantic Richfield employees should be consulted for additional information, 
particularly the security patrols. For example, a general memorandum to a11 employees on the Hanford Reservation might reveal a number of great horned owls (Bubo virginianus) nesting on the reactors and red-tailed hawks (Buteo jamaicensis) nesting on power line towers and poles.

\section{RESULTS AND DISCUSSION}

\section{REGIONAL ACCOUNTS}

Region I. ALE Reserve. Most of the ALE Reserve, in particular the upslope of Rattlesnake Mountain, the mountain itself, Cold Creek Valley, and the general area of Rattlesnake Springs and the Benson Ranch. This region lies generally southwest of Highway 240 , but does not include the western edge of the entire Hanford Reservation (see Region $X$ ).

This virtually treeless expanse of bunch grass prairie is not suitable for nesting by most large raptors. Three areas are of interest: 1) The summit of Rattlesnake Mountain has escarpments with adequate vertical extent for great horned owls and prairie falcons (Falco mexicanus) to nest, but none were found. 2) Cold Creek Valley appears to be prime nesting habitat for marsh hawks, particularly where tumbleweeds collect in low spots, such as near Benson Ranch. I observed several pairs of marsh hawks courting near Benson Ranch on 9 April 1973 and it was evident that they were not on migration. 3) The trees around Rattlesnake Spring, Benson Ranch and just northwest of the IBP grazing plots are excellent Swainson's hawk nest sites. Neither Rattlesnake Spring nor Benson Ranch were checked after the Swainson's hawks arrived; routine Battelle field work should fill this gap. The trees at the abandoned farmstead near the IBP grazing plots had apparently been unused for a number of years judging from the absence of stick nests in or below the trees.

Region II. Horn Rapids Road. A small area close to North Richland and the 300-Area, including land on both sides of Horn Rapids Road along its entire length. Unlike all other parts of the Hanford Reservation, 
this region had a high population of Townsend ground squirrels (Spermolphilus townsendii) and fair numbers of black-tailed jackrabbits (Lepus californicus) on which the only pair of hawks found in the area, a pair of red-tailed hawks, relied heavily (see below).

It was evident that the trees south of Horn Rapids Road near the abandoned canal were visited too often by townspeople to allow birds of prey to nest consistently, although the scattered trees between the canal and North Richland, those some distance from a road or trail, may have been sufficiently isolated. The western 7 or 8 square miles of Region II appeared to be treeless, sandy, sagebrush country of little importance as raptor nesting habitat.

Region III. Wye Barricade. A large, generally barren sagebrush area from Horn Rapids to the old town of Hanford in north-south extent and from the Columbia River to Army Loop Road (approximately) in east-west extent. No hawk nests were found in this virtually treeless area, although large sections away from paved roads were not covered closely. For example, a 25 square mile area south and east of the old town of Hanford (Township 12 North, Range 28 East, Sections 5-9, 15-23, and 26-35) was not covered. Other large tracts of land which were not surveyed are shown on the map provided (Figure 1). There could have been trees with nests in those unstudied areas.

I view the Wye Barricade region as a relative void with regard to nesting raptors--an area where nest sites for sure, and prey populations, possibly, were unavailable and/or inadequate. It represents an excellent area for raptor management, provided the prey base proves to be adequate.

Region IV. Army Loop Road, 200-Area. A large area bounded by Highway 240 on the south and west, the Yakima Barricade-Hanford Road on the north, and the eastern portion of Army Loop Road (approximately) on the east. Included are several square miles northeast of the $200 \mathrm{E}$ reactor area.

Region IV is much like Region III except that trees exist near at least six old gun batteries and/or abandoned farmsteads, and near one or 
more permanent ponds. Of the seven sites known to me, five were occupied by Swainson's hawks (Buteo swainsoni), one by common ravens (Corvus corax) and one by great horned owls in 1973. This total occupancy of Region IV by raptorial or semi-raptorial species may indicate that: 1) prey populations are adequate for some raptors, at least, throughout the relatively "barren" regions of the Hanford Reservation; 2) making artificial nest sites available in Region III would be a fruitful management program; and 3) higher densities could be attained even in Region IV if more nest sites were available.

Region V. Hanford and White Bluffs Townsites. An area with scattered and locally dense stands of trees near the old towns of Hanford, White Bluffs and East White Bluffs along the west bank of the Columbia River. Signs of past human habitation are nearly everywhere either in well planned, but now leveled townsites, near long abandoned farmsteads, beside old irrigation ditches, or in large, now mostly unproductive orchards and vineyards. Region $V$ is excellent nesting habitat for buteos, American kestrels and great horned owls, as was attested by the density of one pair of large raptors for every 2.25 square miles in this 27 square mile area (or 44.4 pairs per 100 square mi les).

The nests of fourteen pairs of raptors noted in this area include the following: four red-tailed hawk nests, five Swainson's hawk nests, three great horned owl nests and two American kestrel nests. There could have been many more pairs of kestrels and, perhaps, two more pairs of Swainson's hawks inadvertently missed, although nearly every tree in the area was checked once or twice from no further away than an eighth mile with the spotting scope. There could also have been great horned owls nesting in or on various buildings, especially those in the 100F reactor area.

Region VI. East Bank. A thin strip along the east bank of the Columbia River from Wahluke to a point opposite the southern edge of the old town of Hanford. Included are the White Bluffs themselves and a half dozen or so abandoned homesteads and orchards. 
Along the East Bank we found two pairs of great horned owls and two pairs of red-tailed hawks, and observed one pair of ravens and four single or pairs of American kestre7s. Two passes along the river--once each way-is certainly not adequate to discover all pairs of kestrels, but the number of large raptors found should be quite accurate. Each grove of trees along the east bark was walked with the exception of the grove directly across from the East White Bluffs boat launch. No islands were visited.

of particular note along the east bank were several common pigeon (Columba livia) colonies and thousands of starlings (Sturnus vulgaris) which have infected the small cracks and crevices of the river bank. Chukars (Alectoris graeca), ring-necked pheasants (Phasianus colchicus), California quail (Lophortyx californicus), waterfowl and passerines on one or both banks probably represent an adequate prey base for prairie falcons. Their absence is keyed to the unavailability of nest sites (see below).

Region VII. Northern River Strip. The south bank of the Columbia River from the western edge of the old town of White Bluffs to the Vernita Bridge with the Fire Station--Pierce Road as the southern boundary (in genera1). This area includes the only reactor now in use as well as the tip of land extending toward the bend in the river near Wahluke.

This area was not adequately covered partially due to time limitations, but mostly due to the presence of reactor areas. It is felt, however, that the raptor populations in the area will not be high; the river bank and adjacent lands apparently were never heavily settled and trees were never planted. Past human habitation (with the accompanying trees) and the extent of past and present reactor activity are the major differences between the Northern River Strip and the Hanford and White Bluffs Townsites (Region V). The combination of less past human habitation and more reactor activity along the Northern River Strip has kept the raptor populations low, the first mentioned circumstance being more important than the latter. Raptors need nest sites--trees in most cases--and, as was seen in the Wye Barricade region, any number of years of relative seclusion of an area will not in itself allow high raptor populations to exist. 
Two raptor nests were found in the Northern River Strip: one longeared owl (Asio otus) nest and one red-tailed hawk nest. The red-tail nest was a significant finding in that the birds used a nest on a steel electric transmission tower. The extent to which buteos and owls use steel towers on the Hanford Reservation is unknown; not many power lines were driven in search of nests. It is important that the line on which the birds nested went to an inoperative reactor, but the relevance of this was not that the flow of electricity was turned off or below capacity, whatever the case may have been. Rather, these towers apparently had not been inspected frequently or maintained in recent years as evidenced by the absence of a well traveled road underneath them. The power lines I was able to follow on adequate roads or trails did not have raptor nests, although one active raven nest was noted in such a situation.

The use of steel towers by raptors is not new; it occurs in many parts of the country and involves many species. Two or three pairs of red-tails use steel towers not far from Priest Rapids Dam. On the Hanford Reservation where the land is literally shackled in place with electric lines of one sort or another, the steel towers, double wooden poles and even smaller poles carrying distribution lines could be put to good, raptor (and nonraptor) management use.

Region VIII. Gable Butte-Gable Mountain. The general area surrounding the mountain and the butte, including the escarpments west of Gable Butte toward Vernita Bridge. Gable Butte has many excellent cliffs on which raptors could nest. Gable Mountain, on the other hand, has only one series of superior cliffs, i.e., on the west end of the south side. No large raptors were found nesting on Gable Mountain, although it was not thoroughly walked like Gable Butte.

Two pairs of red-tailed hawks, one pair of prairie falcons and one pair of great horned owls nested on the cliffs of Gable Butte in 1973. In addition, a pair of crows or ravens nested on a steel tower in the southcentral part of Region VIII and a pair of ravens nested on the escarpments near the approach to Vernita Bridge. Raven nests are included here as possible future (and past) sites of red-tailed hawk nests. 
Region IX. Umtanum Ridge. The narrow river flat and the steep, escarpment-dotted hillside overlooking the Columbia River from the Vernita Bridge upstream 7 miles to the Yakima County-Benton County line. Only the eastern 4-3/4 miles of this region is on the Hanford Reservation. The same kind of habitat extends about 5 more miles upstream to a point 2 to 3 miles above Priest Rapids Dam.

As expected, this region had the highest density of raptors, including, at least, two pairs of red-tailed hawks, three pairs of great horned owls, five or six pairs of prairie falcons, and ten to fifteen pairs of American kestrels. (Kestrel nests were not actually located.) Because of the time limitations, a prairie falcon eyrie was considered occupied if a pair actively defended a cliff. It should be noted that unless every escarpment is checked closely on foot--particularly the second and third tiers of cliffs--most of the prairie falcon nests will not be found. Great horned owls and red-tails nested on the first tier of cliffs or in the deeper ravines which run up the hillside. Kestrels were found nearly everywhere, the cracked, basalt cliffs affording nearly unlimited nesting opportunities. The only pair of burrowing owls was seen on the flat just north of Riverland siding.

Region $x$. Snively Ranch-Highway 24 . The extreme western part of the Hanford Reservation south of Umtanum Ridge to the Rattlesnake Hills in the area of Bennett and Snively Ranches.

Except for four groves of trees just north of Highway 24, this area was not checked. No raptors nested in those four groves, although two of them were excellent sites.

\section{SPECIES ACCOUNTS}

Prairie Falcon

Seven pairs of prairie falcons were found nesting on the Hanford Reservation--on Gable Butte (actually in an inner valley of the eastern portion of the butte) and from a mile west of the Midway Substation to the 
Yakima County-Benton County Line along Umtanum Ridge. None were found on the East Bank (Region VI) along the White Bluffs, although there were other possibilities between the old town of Hanford and Richland which were not covered adequately due to time limitations.

The absence of prairie falcons on the west end of Gable Mountain near the borrow pit was unexpected. Except for Umtanum Ridge, the best prairie falcon site on the Reservation is the vertical cliff overlooking the pond by the borrow pit. There may not be a ledge or cavity of adequate size for prairie falcons on that cliff, in which case one should be provided immediately.

The lack of prairie falcons on the White Bluffs--at least in 1973-was also unexpected. A trip down the river quickly revealed the reasons. First, only two cavities of adequate size were available on the 16 miles of river from Wahluke to Hanford, although the vertical drop was sufficient in many places. Both cavities were occupied by great horned owls which, because of their habit of nesting early, had first choice of nest sites. Second, more nest sites were not available because of the continual caving away of the river bank. When a site is created by a cave-in, it is short lived--in terms of years--thus allowing no constancy of occupation. Historical occupancy of nest sites is an important aspect of the perpetuation of nesting populations of large falcons and many other birds of prey. A prime example of this is an eyrie in the basalt cliffs of Umtanum Ridge which was active in the early 1960's and in 1973. The same exact cavity was used a decade ago and it is likely that the eyrie has been used for decades, if not centuries. This cannot happen on the white Bluffs where the river continualiy eats away at the bank.

Although prairie falcons have probably nested on White Bluffs in the past, the population could go no lower than the situation in 1973. Being void of prairie falcons, these bluffs represent an important experimental area with regard to management through habitat improvement.

An important aspect of such experimentation is the nearby reservoir of nesting prairie falcons on Umtanum Ridge and, to a lesser degree, 
BNWL -1790

Gable Butte. Judging from the density of prairie falcons along Umtanum Ridge, the population must be very healthy. There is at least one pair of falcons for every 0.67 miles of ridge from the substation to the county line. There could be as many as fourteen pairs in the 9 miles upstream from the substation. Young birds from these eyries (and dozens more within 50 miles of the White Bluffs) could form a nucleus for a new, permanent population of prairie falcons nesting in artificial eyries on the White Bluffs.

The prairie falcons of Umtanum Ridge are relatively secure. Most of the falcons nest high on the ridge, a very steep hillside of loose talus slopes; walking across slope is even more difficult than climbing up and down. In addition, prairie falcons are protected in washington and their take for falconry is strictly limited. Furthermore, there are many easier places to acquire prairie falcons in the state of Washington. The outlook for the Umtanum Ridge population is excellent.

So, too, is the outlook for the pair nesting on Gable Butte, provided they are left alone. It would not hurt to visit them two or three times per year. If this is done, walk in from the power line which crosses the southern two quarters of Township 13 North, Range 25 East, Section 14. There is an old road (actually a trail) into the little valley, but it has not been used for years; hopefully it will remain unused, since the eyrie is secluded, picturesque and "one of a kind" in the Gable ButteGable Mountain region.

American Kestrel

The kestrels noted in 1973 were concentrated in three regions: 1) Hanford and White Bluffs Townsites, 2) East Bank and 3) Umtanum Ridge. These small falcons occurred in good numbers, but they did not, apparently, take full advantage of the Hanford Reservation; many regions could have supported more kestrels. This was probably a result of the unavailability of nest sites and competition with starlings and other birds for nest holes. Undoubtedly, artificial nest boxes would attract a great many kestrels to the area. 
BNWL -1790

Red-Tailed Hawk

A total of twelve pairs of red-tailed hawks were found nesting in 1973 with the highest concentration (four pairs) in or near the old town of Hanford. The remaining eight pairs were widely scattered, from the 300-Area near North Richland to Wahluke and across to Umtanum Ridge. These hawks were quite versatile in their choice of nest sites; trees (both alive and dead), river banks, basalt cliffs and steel power line towers were all used in 1973. Large poplar trees close to the river were preferred. The river posed no barrier to the pairs nesting immediately adjacent to it; cross-river activity was noted on two occasions.

Great horned owls apparently did not compete to a large degree with red-tails for nest sites, since the owls preferred cavities in basalt cliffs, river bluffs, and abandoned buildings, rather than trees. Those red-tails nesting on cliffs used open ledges, not cavities. Some redtails occupied nests which would have been acceptable to Swainson's hawks, because the latter also nested in trees, but Swainson's hawks did not nest immediately adjacent to the river. Thus, differential utilization of available nesting habitat, in part, kept the two buteos and great horned owls spatially separated.

Although only two red-tailed hawk nests were climbed to determine food habits, the results were quite interesting. On 8 May the red-tailed hawk nest near North Richland was climbed. There were twenty Townsend ground squirrels, seven small black-tailed jackrabbits and one fledgling western meadowlark (Sternella neglecta) heaped in the nest around two very smal1, young hawks. Ground squirrels and jackrabbits had been previously noted in this area, but nowhere else on the reservation with the exception of ground squirrels on Rattlesnake Mountain. Subsequently, the nest on the steel tower near the fire station in the Northern River Strip was checked. The nest contained one young hawk, one apparently developed egg with a large, dead embryo, one small Great Basin gopher snake (Pituophis melanoleucus deserticola) and two western yellow-bellied racers (Coluber constrictor mormon). 
Although snakes are a common food of red-tailed hawks, I do not believe that reptiles would ever be preferred to rodents, particularly when young hawks have just hatched--a time when food is generally brought in overabundance (as seen in the extreme at the nest near North Richland).

These scant data seem in line with the general feeling which developed during the field work that the prey base, as well as the unavailability of nest sites, limited some raptor populations in the interior of the Hanford Reservation. The red-tail was an example. These hawks nested where habitat diversity was the greatest--where cliffs or trees were available for nest substrates and shelter was available for prey. In the homogeneous bunch grass prairie, sagebrush flats or sand dunes there were no buteos. Where trees occurred in such areas, for example the Army Loop Road region, Swainson's hawks not red-tails moved in. The apparent food problem of the red-tails nesting on the steel tower may have been indicative of what occurs in marginal red-tail nesting situations. The Swainson's hawk, on the other hand, is a more versatile predator of small animals, particularly insects and fledgling birds, which might be readily available in the bunch grass-sagebrush-sand dune areas. In any event, the above opinions point out one of the prime areas of fruitful research on the Hanford Reservation-the study of limiting factors of raptor populations.

Swainson's Hawk

The first Swainson's hawk was observed on the Hanford Reservation on 10 April 1973, almost to the day when the first Swainson's hawks were seen in 1971 and 1972 on the Pawnee National Grassland in northeastern Colorado. Since the bird seen on 10 April was the only one observed in 3 days of field work from 9-11 April, it certainly was one of the earliest arrivals of the year.

Swainson's hawk nests were concentrated in two general areas on the Hanford Reservation: 1) Army Loop Road, 200-Area and 2) Hanford and White Bluffs Townsites. In general, they nested wherever sites were available, although it was apparent that many excellent nesting situations in the the scattered trees north of the old town of Hanford were not put to full use. 
Of particular interest with regard to Swainson's hawks are the following: 1) They did not nest closer than half a mile to the river; most sites were more than a mile from the Columbia. 2) Nearly all Swainson's hawk nests in the area were in man-created situations. With only a few exceptions, Swainson's hawks must have been excluded from the Hanford Reservation before man arrived in the late 1800's. 3) Swainson's hawks have been able to inhabit areas (Army Loop Road, 200-Area) that other raptorial birds (notably red-tailed and ferruginous hawks, Buteo regalis) have not. 4) Should management of this species ever become necessary, the Hanford Reservation has excellent possibilities for increasing wild population levels and improving nesting habitat. Other information concerning Swainson's hawks is included in the next section.

Ferruginous Hawk

No ferruginous hawks were seen or found nesting on the Hanford Reservation in 1973, al though many excellent nest sites were available. The area between the Midway Substation and Gable Butte provides good ferruginous hawk nest sites, as does the north side of Gable Mountain, the Hanford and White Bluffs Townsites, and Rattlesnake Mountain on the ALE Reserve.

The absence of ferruginous hawks must be the result of low numbers of Townsend ground squirrels, black-tailed jackrabbits and cottontail rabbits (Sylvilagus nuttallii). In the case of ground squirrels, early estivation and subsequent hibernation essentially removes this prey resource at a time (June) when the maximum number would be needed to feed growing young. No jackrabbits were seen north of Horn Rapids Road during the field work herein reported. Cottontails were observed only in a few places, notably around some of the old gun batteries along Army Loop Road.

On the Hanford Reservation a gamut of situations with regard to nesting by the three buteos of western North America is represented. Food habits studies have shown that Swainson's hawks take more species of prey than do ferruginous hawks in a given locality (01endorff, 1973). Swainson's hawks are more generalized predators. That red-tailed hawks fall somewhere in between would be an educated guess. This follows from the fact that the 
number of small species of animals generally exceeds the number of larger species in an area, and smaller hawks prey on smaller animals.

Thus, in the Wye Barricade region there may have been adequate prey for the smallest, most generalized buteo (Swainson's hawk), but no nest sites were available. In the Army Loop Road, 200-Area region there was adequate prey and nest sites for Swainson's hawks, but inadequate prey and/ or only marginal nest sites for red-tailed hawks. In the Hanford and White Bluffs Townsites there were adequate prey populations and suitable nest sites for both red-tailed and Swainson's hawks. Nowhere on the Hanford Reservation were prey populations sufficiently high for the most specialized and largest of the buteos (i.e., ferruginous hawks). Specifically, there were not enough ground squirrels and/or rabbits. Quantitative proof of these relationships would be a fruitful avenue of raptor research on the Hanford Reservation.

Golden Eagle

The golden eagle (Aquila chrysaetos) was also absent from the Hanford Reservation in 1973. This probably stems from the same reasons that ferruginous hawks were absent, i.e., the scarcity of mammalian prey. The larger the raptor, the higher the percentage of mammalian prey in the diet (both by numbers of prey and biomass) (01endorff, 1973). The lack of ground squirrel-to-jackrabbit sized animals precluded nesting by the two largest raptors (golden eagles and ferruginous hawks) which would conceivably nest in the area if conditions were right.

Marsh Hawk

The number of marsh hawks on the Hanford Reservation could exceed 25 pairs, the highest concentration being on the ALE Reserve along Cold Creek. More important than their numbers, however, is the fact that their behavior is apparently unaltered in the relatively pristine, undisturbed area of the Hanford Reservation. An excellent two-summer project would be a study of the reproductive behavior, population dynamics and food habits of marsh hawks on the ALE Reserve. Long-term study of the ALE 
population would certainly add to the growing evidence that harrier numbers are precisely controlled by rodent numbers.

Burrowing Ow1

Burrowing owl observations were limited to the sighting of one bird between the Midway Substation and the Vernita Bridge. Ecosystems Department staff have additional field information regarding this species.

Long-Eared Ow1

Oniy one nest of this species was located. It was in a willow stand along the Columbia River about 3 miles downstream from the Vernita Bridge. Two small young were in the nest on 11 May. I believe there could be a half dozen more pairs of these owls on the Hanford Reservation, but finding them would take many hours of walking the willows.

Great Horned Ow]

This large owl is the most conspicuous and, perhaps, the most abundant strigiform bird on the Hanford Reservation. Like the Swainson's hawk, the great horned owl is a generalized feeder capable of preying on the smallest rodents, the largest lagomorphs and large game birds. Sti11, the ow1s do not appear to be as opportunistic in moving into new areas settled and subsequently abandoned by man. On the Pawnee National Grassland Swainson's hawks and ferruginous hawks occupy man-created nest sites in relatively unbroken grassland much more consistently than great horned owls which, even today, occupy traditional territories in gallery forests along usually dry creeks or around cavities in cliffs.

On the Hanford Reservation great horned owls continue to nest near the Columbia River along the White Bluffs and Umtanum Ridges, and in the cliffs of Gable Butte. Only a few have dispersed away from the river into nesting situations created by man. Notable examples include the nest below the east end of Gable Mountain, the nest on the 105B reactor which has been active for about 20 years, and the nest in a small grove of trees near the 200W. The latter two nests were not visited by this writer in 1973. 
BNWL- 1790

Great horned owls probably prevent prairie falcons from nesting on the White Bluffs by nesting extremely early in the season. When prairie falcons arrive in the spring, the owls cannot be evicted, and nowhere along the White Bluffs do two sites occur close enough for intraspecific competition between owls to allow interspecific occupancy of the same cliff by owls and falcons. The other extreme is seen on Umtanum Ridge where there are so many escarpments that both owls and falcons can occupy different cliffs. It is possible, however, that the density of falcons in the 3 miles nearest the county line is so high that the falcons have prevented the owls from nesting by killing all owls which have attempted to nest in the area in the past, thereby destroying any constancy of nest site use by the owls. Prairie falcons viciously attack great horned owls at every opportunity.

COMPARISON WITH NORTHEASTERN COLORADO (PAWNEE)

The large raptor fauna of the Hanford Reservation is not as rich in species as that of the Pawnee National Grassland in northeastern Colorado due to the absence of nesting ferruginous hawks and golden eagles. The total number of pairs of large raptors may not be significantly different, however. On the basis of my findings there were about 11 pairs of large raptors per 100 square miles on the 400 square miles of the Hanford Reservation in Regions I-IX. If an estimated 20 percent of the buteos and owls were missed in 1973 (e.g., great horned owls on reactors, red-tails on steel towers, all raptors in places where access was limited, Swainson's hawks in trees not checked on the final field trip, etc.), the population density would be 14 pairs per 100 square miles. Adding, conservatively, another 10 pairs of marsh hawks, the density would be about 16 pairs per 100 square miles, precisely the density on the 1,000 square mile study area in northeastern Colorado in 1972 (0lendorff, 1973). Although this juggling of numbers is strictly academic, a thorough search of the Hanford Reservation would probably reveal as many, if not more, large raptors per unit area than on the Pawnee. 
On the Hanford Reservation red-tailed hawks, Swainson's hawks and great horned owls occurred in nearly equal numbers in 1973, about 12 to 15 pairs of each in the 400 square mile area, while there were about half that many prairie falcons. In 400 square miles of shortgrass prairie in Colorado there would average about 27 pairs of Swainson's hawks, 10 pairs of ferruginous hawks, 12 pairs of great horned owls, 5 pairs of golden eagles, 3 pairs of red-tailed hawks and 6 pairs of prairie falcons. There probably were no marsh hawks nesting on the 1,000 square mile study area in Colorado in 1973, while this species figured strongly at Hanford (perhaps as the most numerous large raptor).

One striking difference between Hanford and Pawnee was that raptors were more uniformly distributed on the Pawnee, although clumping in ecologically suitable habitat was evident in both areas. For example, in the southern 142 square miles of the Hanford Reservation I located only 1 pair of raptors (or 0.7 pairs per 100 square miles). In the northern 133 square miles I found 38 pairs (or 28.6 pairs per 100 square miles). On the Pawnee the lowest density of large raptors in 1972 was 9 pairs in 144 square miles (4 townships) (or 6.2 pairs per 100 square miles). The highest density was 33 pairs in 144 square miles (or 22.9 pairs per 100 square miles). In the best cliff habitat both on the Pawnee and Hanford, densities reached 11 pairs of large raptors in 5 square miles (or 220.0 pairs per 100 square miles).

Thus, the densities of raptors in the best habitats on Hanford (1973) and Pawnee (1972) were comparable. Averaged over 130 to 150 square mi les, Hanford had more large raptors (28.6 versus 22.9 pairs per 100 square miles). The magnitude of this difference was certainly greater than the data indicated because the 28.6 figure for Hanford included only the nests I found and excluded most marsh hawks. The figure for Pawnee was very accurately determined during two summers of field work. It is important to note that Pawnee had three separate 144 square mile areas where densities were over 20 pairs per 100 square miles, while Hanford had only one such area.

In low density areas Pawnee had more raptors (6.2 versus 0.7 pairs per 100 square miles). This difference resulted from the past influence of man 
on the two study areas. Pawnee was quite uniformly settled during the early decades of the 1900's, with a farmstead on virtually every section (see 01endorff, 1973, for detai1). Hanford, on the other hand, apparently was not uniformly settled. Much of the Wye Barricade region was not settled at all. Only a few scattered ranch houses were built in the ALE Reserve and the Army Loop Road, 200-Area region. The Hanford and White Bluffs Townsites were densely irhabited and then abandoned; trees planted by man, and natural trees (if they existed), now are as thick in this region as in many parts of the Pawnee. Most towns on the Pawnee are still inhabited, however. The Gable Butte-Gable Mountain, Umtanum Ridge and East Bank regions have higher raptor populations for a different reason--naturally occurring habitat.

The result of man's uniform settlement of the Pawnee was that Swainson's hawks were better able to make use of that area than, for example, the Wye Barricade region and the southern three-quarters of the ALE Reserve on the Hanford Reservation. Raptor nesting density in the Army Loop Road, 200-Area region ( 7.6 pairs per 100 square miles) was comparable to the lowest density on the Pawnee (6.2 pairs per 100 square miles). The Wye Barricade region was one step lower ( 0.0 pairs per 100 square miles) due to the near tota 1 absence of trees.

The influence of rivers and creeks on Hanford and Pawnee is also an interesting comparison. Pawnee has many creeks like Hanford's Cold creek--usually dry, but sometimes, after heavy rains, flowing very heavily. Apparently, more opportunities for cottonwoods and willows to take root in damp areas existed on the Pawnee; natural trees are now more abundant there than at Hanford. On the Pawnee, Crow Creek runs for about 1 month steady each year, just enough to allow a nearly continuous, although thin, band of trees to grow. It is surprising that the Columbia River has had no such effect, except for a few scattered stands of willows, along its banks. For raptors, Crow Creek on Pawnee is much more important than the Columbia River at Hanford. On the two study areas there was (in 1972) one pair of large raptors for every 1.2 miles of Crow Creek, compared with one pair per 2.6 miles of the Columbia River from the Benton County-Yakima County line downstream to the old town of Hanford (in 1973). 
BNWL-1790

\section{THE PRIORITIES OF RAPTOR FIELD RESEARCH}

There is a pausity of information concerning raptorial birds which could be used in ecosystem analysis and/or knowledgeable management and conservation of wild populations of avian predators. The major reasons for this dearth of useful data include the following: 1) Most studies of raptor populations have been seasonal and short-term. With some exceptions, substantive raptor research has usually involved only one or two years' data on summer populations, or a one season survey of wintering raptors. 2) Studies of raptor population dynamics have typically included one or two common and/or spectacular species, often only in their dominant habitat along a cliff line, river or gallery forest. Most major raptor studies suffer from these biases, biases resulting from the determination of densities of only selected species in selected habitats (ecological densities), as opposed to densities of all raptors in an area representative of the total habitat used by the total complement of birds of prey (crude densities). 3) Studies of population dynamics and food habits of raptors usually have not been conducted in conjunction with simultaneous, quantitative studies of prey population levels. Rarely is the subject of energy flow from prey to raptors discussed in the literature, because of the lack of prey population estimates on which to base calculations of rates of exploitation.

A multifaceted, penetrating approach must be made if quantitative data concerning population dynamics, ecological impact, management and conservation are to be synthesized, and this must involve relatively large land areas such as the Hanford Reservation or the Pawnee National Grassland. Synthesis of concepts from biased population studies carried out in different years, in widely scattered areas, on one or two species at a time, with varying techniques and without simultaneous study of prey populations is not the most fruitful approach to problems raised by ecosystem analys is and the urgent need to manage birds of prey in the wild.

The following studies will be suggested below: 1) a study of management techniques and emergency conservation measures applicable to raptorial birds, and 2) a study of limiting factors limiting raptor populations. 


\section{INDUSTRY AND RAPTOR RESEARCH}

The first 1isted study is widest in scope and the most costly, but it would also have the greatest impact on science and is the most timely. Birds of prey are the "birds of the hour," so to speak, because they are being poisoned, shot, electrocuted, taken from the wild for research, falconry and zoological gardens, forced from their nesting habitat by photographers, hikers, picnickers, etc., all at a time when the cause of wildlife is being championed nationwide. In addition to these immediate or proximate factors which decrease raptor numbers, there are several subtle, ultimate causes of raptor population decline such as irreversible habitat destruction, continuing global development of intensive agriculture and attendant use of chemicals, and continuing emission of environmental pollutants in general.

In the latter context the study of raptorial birds may have something to offer the Atomic Energy Commission. Large numbers of raptors in an area attest, at least circumstantially, to the fact that the area is either free of certain pollutants, or that the pollutants are at low levels, or that the chemicals are not detrimental to the ecology of the area. This follows from the fact that birds of prey, as end of the food chain organisms which concentrate certain pollutants in their tissues, have proven to be important barometers of environmental contamination.

Scientists, naturalists, conservationists, and mankind in general all stand to benefit from basic and applied research aimed toward management and conservation of birds of prey as a low resolution, but nevertheless proven effective, long-term "warning" system of environmental contamination. Raptorial birds have played an important role in the DDT controversy; they could play an equally important positive role in the environmental justification of nuclear power plants as well as being an important parameter for long-term monitoring of the ecological impact of nuclear installations.

The arguments would center around that fact that there are probably more raptorial birds on the Hanford Reservation now than before white man came to the area--more now than before the Atomic Energy Commission took 
over. It is noteworthy that birds of prey now utilize a number of mancreated nesting situations, but it is even more relevant that this has occurred in spite of any effect reactor activities and radiation research may have had on the wildlife of the Hanford Reservation during the past 30 years. This point could be brought further to light by increasing raptor populations on the Hanford Reservation to still higher levels through habitat improvement and artificial increases in annual productivity--much discussed programs at present (see below).

In short, many believe, as I do, that certain industries, for example the electricity industry, could benefit greatly from the favorable "ecological publicity" which would follow funding and implementation of a study of conservation and management techniques of raptorial birds. The first industrial complex or agricultural interest--be it the livestock, agro-chemical, timber, petroleum, or nuclear power industry--which finances such a project, particularly if the research will benefit threatened species will receive the plaudits of much of the American public, including some of the antagonistic environmentalists. Much of what I recommend could justifiably be exploited in mass media advertising to help maintain the erect environmental posture of the electric and nuclear power industries. Federal and state governmental agencies are wasting valuable time in this research area which remains wide open in the United States; industry could effectively steal the show.

\section{A STUDY OF MANAGEMENT TECHNIQUES AND EMERGENCY CONSERVATION} MEASURES APPLICABLE TO RAPTORIAL BIRDS

It was suggested in 1965 during the conference of peregrine falcon populations at the University of Wisconsin (Hickey, 1969) that one outcome of the conference should be "imaginative research and action... to determine the extent that management of birds of prey is possible" (M. W. Nelson, 1969, p. 407). It is an understatement to say that the concept of raptor management still lacks field tested techniques--techniques which wildlife agencies throughout the world urgently need to activate programs to save 
endangered species of hawks, eagles and falcons. Nevertheless, at the recent Conference on Raptor Conservation Techniques, it was shown that the potential for raptor management is great.

The Atomic Energy Commission Hanford Reservation, administered by Battelle, Pacific Northwest Laboratories, provides nesting habitat and food for varying numbers of several species of raptorial birds, both large and smal1. Prairie falcons, red-tailed hawks, Swainson's hawks, American kestrels, marsh hawks, great horned owls, and burrowing owls occur in the area in numbers adequate to successfully field test management techniques for several genera of North American birds of prey. If necessary, areas outside (but near) the Hanford Reservation could be used to widen the research potential to include golden eagles, ferruginous hawks and anatum peregrine falcons (Falco peregrinus anatum), all of which probably inhabited the Hanford Reservation in years past, but which are now absent within its boundaries.

It should be noted that, in addition to being considered a threatened species, the prairie falcon is the only large falcon which is sympatric with the endangered anatum peregrine falcon. Both of these falcons historically occupied the drainages of the Columbia and Snake Rivers. This fact is significant relative to the conservation and management of this endangered subspecies of the peregrine falcon (see below). Similarly, red-tailed, Swainson's and ferruginous hawks (the latter a species on the Audubon Society Blue List indicating some conern) are buteos like the endangered Hawaiian hawk (Buteo solitarius). The use of ecological, phylogenetic or physical "near-equivalents" of endangered species has been part of the endangered species program almost since its conception. There is no hurdle to extending this line of reasoning to field management studies, since many raptor management techniques will prove to be genus-specific, more so than species-specific. Some techniques will be applicable even beyond generic limits. Neither is there a hurdle (except for funding) to making the Hanford Reservation the first major raptor management area and testing ground for conservation techniques which could have worldwide applicability. 
The specific advantages of doing field management studies of birds of prey on the Hanford Reservation include the following: 1) considerable background information concerning many aspects of the grassland ecosystem which has come and continues to come from the efforts of Battelle's Ecosystems Department personne1, 2) the existence of an area relatively free of direct interference by the general public, 3) adequate numbers of raptors, and 4) the general advantages of working in grasslands, such as the lack of diversity of nesting habitats, the sparseness of forests, the excellent overall visibility and ease of mobility--all of which are necessary prerequisites to raptor studies involving large land areas. Virtually no ecosystem in North America other than grasslands allows study of large enough land areas to evaluate adequately the use of that ecosystem by birds of prey.

Objectives of a raptor field research program should be:

1) To develop widely applicable management techniques for raptorial birds directed, primarily, toward increasing existing population levels;

a) To provide artificial nest sites and to improve natural nest sites for selected species, thereby illustrating that raptor populations can be increased by allowing more complete utilization of suitable nesting habitat, unprecedented utilization of marginal nesting habitat, and more thorough exploitation of prey resources;

b) To avert numerous types of nesting failures of raptors (such as wind- and rain-caused nest destruction, disease and parasite infestations, and desertion due to human interference) in order to increase productivity of existing populations;

2) To develop emergency conservation measures for threatened or endangered species of raptors in order to prevent regional extirpation and total extinction; 
BNWL-1790

a) To research methods of increasing annual productivity of selected species in the wild through clutch-size manipulations during egg-laying;

b) To research the feasibility of foster parentage as a vehicle for re-establishment of decimated raptor populations and revitalization of remaining, nonviable populations with new breeding stock;

c) To develop other methods of reintroducing young, captivebred or displaced wild eyasses and/or fledglings to ecologically adequate but geographically new situations;

d) To research methods of artificially incubating raptor eggs using, at least, statistically significant numbers of Swainson's hawk eggs and, possibly, prairies falcon eggs depending on the outcome of experiments with clutch-size manipulations.

Proposed Experiments

Artificial Nest Structures; Nest Site Improvement

There are three areas of cliffs on the Hanford Reservation: 1) White Bluffs, 2) Gable Mountain and Gable Butte, and 3) Umtanum Ridge. Umtanum Ridge has a high nesting density of prairie falcons. The other two areas are now unoccupied by prairie falcons (except for one pair on Gable Butte) apparently due to the absence of ledges and cavities for nest sites. Providing new nest sites on these cliffs and thereby increasing the population of prairie falcons over several years will be a significant management program for these threatened falcons. In addition, techniques developed and results obtained will indicate the extent to which other populations of large falcons, even endangered species, might be managed in the field. Extension of the nest site construction to other major cliff lines and many small and/or isolated cliffs off the Hanford Reservation will also be attempted to show that new nesting habitat can be created for threatened species. Renovation of sites threatened or already destroyed by erosion, 
and enlargement of ledges and holes of inadequate size for large broods should also prove fruitful. Increases could be spectacular in certain areas where extensive management is done.

There is also some possibility that large falcons could be made to nest away from cliffs, such as in barrels on poles. The nesting of peregrine falcons and gyrfalcons on man-made structures is well known. Of particular note is the use of shallow willow baskets placed in trees by several pairs of peregrine falcons in northern Germany during the 1950's. Such versatility of nesting substrate should be exploited in other large falcons such as prairie falcons. Thus, an experiment has been designed for a part of the study area where it may be possible to entice prairie falcons to use oak barrels on poles. Through the years the strategy would be to develop a barrel-nesting population of prairie falcons from attempts initiated during the study herein proposed and to move this population progressively further and further away from traditional cliff nesting habitat. This is a long-term project, but one worthy of immediate initiation and requiring a minimum of long-term maintenance.

The planned construction of artificial nest structures for hawks and eagles also involves the improvement of existing habitat and the creation of new opportunities for nesting. This will be done to demonstrate the fact that in the face of past, irreversible habitat destruction, endangered species (here "near-equivalents" of endangered species) may be saved from local extirpation or extinction by allowing effective use of remaining optimal and/or marginal nesting habitat (as represented by most of the Hanford Reservation). Artificial nest structures would also serve in research directed toward defining 1 imiting factors of raptor populations. Thus, during the nonnesting seasons of the first 2 years of the proposed study, about 100 to 125 multipurpose nest structures will be erected--structures which might be suitable for falcons, owls, buteos or eagles. In general, the structures will be barrels with platforms on top, mounted on poles placed in typical nesting habitat for the target species. 
BNWL-1790

\section{Averting Nesting Failures}

In northeastern Colorado from 17 prairie falcon nests for which adequate data are available for 1972, 3.24 young fledged per nest. If seven infertile eggs had been viable and seven young falcons infested with bloodsucking mites had been reared, productivity would have been 4.00 young per nest, an increase of over 23 percent. Infertility probably cannot be prevented directly, but fertile eggs taken during "recycling" and indeterminate laying experiments (see below) could be used to replace infertile eggs. There is reason to believe that simple ledge alterations to allow more sunlight into mite infested eyries will alleviate this problem.

The specific problems of raptorial birds on the Hanford Reservation are not known at this time. Nevertheless, problems beset all raptors, particularly during nesting, and these problems often have straight-forward solutions. For example, the simple procedure of posting all known nest sites with no trespassing signs will increase productivity of some species. Raptors often nest in situations which are very vulnerable to the ravages of strong winds. Provision of artificial nest structures or the moving of existing nests a few feet to more stable situations would also increase overal1 productivity.

\section{Clutch-Size Manipulations}

That falcons will "recycle" and lay a second clutch of eggs when the first clutch is removed has been known since the days when egg collecting was an active hobby. Only recently, however, has the potential for indeterminate laying been demonstrated in captive falcons. The latter is a phenomenon whereby birds will continue to lay if the eggs are removed as they are laid, except for one which is left in the nest. Indeterminate laying is untested in wild falcons, yet it may have widespread use as a technique for increasing egg production of endangered species. The research outlined below is designed to test "recycling" (a much used technique in current propagation projects) and indeterminate laying in wild prairie falcons as a means of increasing productivity of a wild population. 
Experiment I. As soon as five eggs are laid in certain eyries, all eggs will be placed in incubators and artificially incubated or in different eyries (up to six eggs per eyrie). If theory prevails, 14 days later the "recycled" birds will begin a second clutch in the same eyrie or one nearby. Some of the "recycled" birds will be left with their second clutches, while others will receive, by trade, their original first clutches so that their young will hatch on the original schedule. This will allow evaluation of the 2-week delay and its effects on productivity. The young which hatch in the incubator will be used to circumvent infertility and nestling losses, and to assure a uniformly high productivity by the entire wild population. Excess birds will be used in reintroduction experiments (see below).

Experiment II. Eyries will be located in which no more than two eggs have been deposited. One egg will be removed from each eyrie and stored in an incubator as will each subsequent egg until a total of 10 eggs are produced by each pair (assuming wild prairie falcons prove to be indeterminate layers). Five eggs will be replaced into the experimental eyries (for a total of six in each eyrie). The excess eggs will be used for other experiments as described elsewhere.

The potential of clutch-size manipulations is to double the production of fertile eggs by wild pairs. However, there is the possibility of failure of the birds to respond to such manipulations. For this reason, it would be wise to do the pilot work on these techniques with prairie falcons rather than peregrine falcons. Depending on the outcome of the prairie falcon experiments, similar work with peregrine falcons should be prohibited or initiated immediately. In fact, work with arctic peregrines could be conducted the same year with full knowledge of the results of the prairie falcon experiments because of the lateness of the nesting season in the far north.

\section{Foster Parentage}

Very few attempts to reintroduce captive-bred birds of prey into the wild have been made. Neither has there been substantive research on 
introducing young raptors or eggs from one population to another, with the exception of ospreys. Thus, methods of reintroducing birds of prey into the wild need to be developed. Not even a location for reintroduction research has been chosen in the United States. Such a location (the Hanford Reservation and adjacent portions of the Snake and Columbia River drainages) is herein proposed as are several prospective methods of reintroduction. This phase of the program could be the culmination, through cooperative reintroduction programs, of several captive propagation projects now in progress.

Preliminary investigations show that raptors will rear young other than their own, even the young of different species. Pilot fostering experiments should precede any attempts to re-establish decimated raptor populations or to revitalize remaining, nonviable populations with new breeding stock. The most crucial fostering experiment would involve reintroducing "anatum" peregrine falcons into old peregrine eyries along the columbia and Snake now occupied by prairie falcons. We are, however, two or more years away from adequate numbers of captive-bred peregrines for even pilot reintroduction experiments and a like number of years away from adequate population information on peregrine falcon population levels. Nevertheless, prairie falcon-prairie falcon and prairie falcon-red-tailed hawk nestling exchanges (at least) will be carried out during the study herein proposed in order to develop the necessary techniques. Specific results would include evaluation of the feasibility of 1) intraspecific and interspecific (as well as intergeneric) exchanges, 2) shifting eggs and nestlings from one population to another, and 3) testing the hypothesis that locally uncommon species (e.g., ferruginous hawks) can be increased in an area by switching the young of that species into nests of the other more abundant, closely related species (e.g., Swainson's hawks). The reasoning is that the rarer birds will return near to their natal home to nest and displace the more common birds through superior competitive abilities or differences in nesting phenologies. 
BNWLL -1790

\section{Controlled Release ("Hacking")}

It has been long debated whether or not birds taken into captivity and later released actually survive in the wild. There is evidence that many have. The following phase of the proposed project is designed 1) to evaluate the technique of "hacking" birds into the wild, particularly fledglings and subadults held in captivity for up to 2 years, and 2) to attempt to demonstrate that birds held in captivity for long periods of time can (after being released or otherwise lost) become part of a breeding population. Successful "hacking" of captive-bred and wild fledglings, and release of eyass-taken birds as adults will have widespread application in the endangered species program for raptors.

Hand-reared, captive-bred young, and wild young from different geographical locations will be "hacked," i.e., allowed to "fledge" on the study area from a shelter in which they will be fed during the late growth period. After the birds "fledge," the shelter will become a feeding station until the birds are independent. Advantage will be taken of the White Bluff area where the cliffs are not now used extensively by prairie falcons because of the lack of adequate nest ledges and holes. In this way, after creation of new nest sites in the low-yield cliffs, if there is any chance at all of reintroduced birds remaining in or returning to the place of reintroduction to breed, there will be ample places to nest and a low level of intraspecific competition to attract the birds. Tne bonus is that long-term followup of the reintroduced birds may be possible under these circumstances in order to determine if the birds enter the new breeding population. The progress of the released birds during the controlled release period will be followed by radio tracking. Of course, like all birds involved in the various phases of the proposed research, these birds will be banded, and recoveries should result from the study area and elsewhere before the end of the 5-year program.

Cade (1971) suggested that falconry could be utilized as a method of carrying birds of prey through the critical subadult period during which the majority perish. Through cooperation between the participants of this 
study, the Cornell Laboratory of Ornithology, several state wildlife agencies, and a number of competent falconers, Cade's plan could be implemented using prairie, instead of peregrine, falcons. Success with prairie falcons would lend further justification to similar programs with peregrines. State wildlife authorities must be asked to issue permits to falconers for the removal of about 20 prairie falcons from the wild. The falconers, by previous agreement, will relinquish the birds for controlled release into the wild 2 years later. The release technique will be similar to that described in the preceding paragraph. This phase of the proposed research would only be instigated with the approval of Cade, the originator of the idea.

\section{A STUDY OF FACTORS WHICH LIMIT RAPTOR POPULATIONS}

The theoretical aspects of animal population dynamics have been thoroughly debated since the importance of density-dependent factors was stressed by Nicholson (1933). Publications disputing the importance of density-dependent factors (Andrewartha and Birch, 1954; Andrewartha, 1961) and accepting, but modifying, Nicholson's theories (Lack, 1954; WynneEdwards, 1962) have added considerable impetus to what Lack (1966) calls "a three-cornered argument on population theory."

Preliminary population studies of the birds of prey of the Pawnee National Grassland in northeastern Colorado ard the Hanford Reservation lead to speculation that availability of nest sites, a density-independent factor, may ultimately limit the size of nesting populations of all raptors present in the two areas during the summer months. Food, at first glance, is not considered to be limiting on the colorado study area, while it may limit populations in some regions of the Hanford Reservation.

Odum (1971: 195) makes the following statement: "In low-diversity, physically stressed ecosystems, or in those subject to irregular or unpredictable perterbations, populations tend to be regulated by physical components such as weather...." The shortgrass and the sagebrush-bunch grass prairies are "low-diversity, physically stressed" ecosystems which are 
BNWL-1790

stressed by extremes of temperature, precipitation and wind. Such factors may be limiting factors in their own right.

Research is needed to sort out the factors which limit raptor populations in the arid western states. The relative importance of each factor should be evaluated. Such considerations will give direction to management efforts with birds of prey. Studies of raptor population dynamics and predator-prey relationships suggested below would show, for a large group of raptors, whether availability of nest sites, prey numbers and/or abiotic factors are limiting, and if density-dependent factors such as reproductive success, nestling starvation, or intraspecific conflict are also important. Selected hypotheses could be tested using applicable management techniques (e.g., provision of artificial nest structures). The results of the suggested study would lend support to or dispute each of the three divergent theories of population dynamics.

Objectives:

1) To study raptor and prey population dynamics on a number of shrubsteppe study areas on or near the Hanford Reservation in southeastern Washington;
a) To census raptor and prey numbers in areas of high, moderate and low raptor densities;
b) To analyze food habits of raptors on the Hanford Reservation;
c) To calculate rates of exploitation of prey by avian predators in areas of different prey availability;
d) To determine long-term trends in crude nesting densities and annual productivities of grassland birds of prey;

2) To develop hypotheses concerning the limiting factors of raptor populations on the Hanford Reservation;
a) To correlate abiotic factors with trends in raptor population numbers;


b) To utilize prey population trends to evaluate the importance of prey in determining trends in raptor populations;

c) To study nesting behavior, differential use of habitats, and preferences for specific nest substrates of each raptorial species to determine if these factors limit raptor populations directly or indirectly;

3) After defining the factors which limit populations of birds of prey on the Hanford Reservation, to exploit those factors in an effort to increase raptor populations locally (see previous section on management techniques and emergency conservation measures).

Raptor Population Dynamics

The feasibility of determining crude nesting densities (pairs per unit total space) and ecological nesting densities (pairs per unit of suitable habitat space) of the large birds of prey in vast areas of grassland is already known. Similarly, productivities of the same birds is also known. Previous studies in Colorado included successful attempts to find, in 1971, virtually al1 of the large raptor nests on a 414 square mile area (01endorff, 1972) and, in 1972, on a 1,000 square mile area (01endorff, 1973). That the same could be done at Hanford was shown by a pilot study in 1973 .

\section{Basic Raptor Population Studies}

Population studies should be conducted in several steps during the study herein suggested: 1) a mile by mile search for active nests should be made each year on the Hanford Reservation (and adjacent areas, if necessary). Such search would yield data on the number of pairs and biomasses of adults of each species per unit area at the beginning of the nesting season. 2) During the weeks after hatch, nests should again be visited to band and color mark young, to remove addled eggs for pesticide analyses, to locate "runts" and diseased birds, and to detect predation, wind destruction and other causes of nest failure. 3) The nests should be visited a third time as the birds fledge to determine nest productivity and to obtain fledging weights for calculations of productivity per pair and biomass production per unit area. 
This basic population study should be conducted during every year of the project. It would be unprecedented since crude and ecological nesting densities of a group of raptorial birds would be determined simultaneously on a large area over a period of several years along with concurrent food habits and prey population studies. The results of such study would allow meaningful calculations of predator-prey biomass relationships (see below).

\section{Nonnesting Season Population Studies}

Studies of migrating and wintering raptors should also be conducted since they have an indirect effect on nesting populations through depletion of prey resources. It is virtually impossible to determine crude densities of migrating and wintering birds of prey on large enough land areas to adequately quantify population levels in all shrub-steppe habitats. If one censuses a large area, say 144 square miles, the census cannot be done quickly enough to avoid resightings, different activity patterns of the birds depending on the time of day, and sudden changes in wind conditions so characteristic of weather in arid grasslands.

The above-mentioned problems reduce the effective censusing methods to the determination of relative ecological densities in different habitats during several consecutive years. But even this approach would be fruitful. It would allow comparisons between habitats and between years. Censuses should be made every 1 to 3 weeks depending on the season along at least one route in each habitat. This should be dorle outside the nesting season, from 15 August through 1 May, during each year of the study. In addition, such censuses would yield follow-up information on the color-marked birds of local nesting populations which may also winter on the study area.

\section{Mortality Studies}

It is not a simple matter to quantify mortality of wild birds. Mortality is a complex factor of population dynamics. Some mortality factors of birds of prey have been determined. Quantification, however, is almost wholly lacking, especially on a long-term basis. For example, some data on wind destruction of nests, avian predation on hawk eggs, external parasites, incubation failure, nestling starvation, human interference and 
electrocution are in hand for the Pawnee National Grassland in northeastern Colorado, yet far more documentation is needed over a number of years in order to evaluate these factors. Similar information could be gathered at Hanford. One must be able to consider the average effects of mortality factors over a period of several years. Such study would be even more relevant at Hanford where human interference is minimal.

Mortality could be approached in at least three ways during the study herein suggested. First, mortality factors should continue to be defined through field observations. Second, each dead hawk, (embryos, nestlings, juveniles and adults) encountered during the study should be examined and a cause of death determined, if possible. In this way, one could calculate the relative importance of each mortality factor (but not how the factors relate to the resident populations). Finally, band returns of several hundred marked birds would probably be available for analysis. Eventually, rough life tables would be calculable for populations of most raptors of southeastern Washington.

\section{The Effects of Environmental Contamination}

One other need is to determine the effects of pesticides and other contamination, particularly on those species eliciting the most concern of biologists and conservationists (e.g., prairie falcon, golden eagle, ferruginous hawk, burrowing $0 w 1$ ), and species which migrate to countries which still use persistent pesticides extensively. (Swainson's hawks migrate to South America.) It must be determined if any contaminants are limiting factors on raptor populations in the study area.

The approach to pesticide pollution during the first 2 years of the suggested study would be minimal, primarily involving collection of unhatched eggs for analysis of eggshell thinning. If thinning is noted, the contents of all unhatched eggs would be analyzed for residue levels. If high levels of contamination are present, further studies with statistical designs to eliminate biases should be proposed. If no eggshell thinning, embryonic mortality, or high residues are found in raptors on their avian prey during these pilot investigations, contamination studies could be adandoned. 
The problem of contamination of food chains through leakage of radioactive waste products might also be evaluated using birds of prey and mammalian predators--the top carnivores--as indices of contamination. Breeding raptors tend to return to the same nest sites year after year. Much could be learned through color marking individual birds and trapping them for assay each year. Doubtless, other important studies could be developed exploiting the concept that birds of prey are excellent barometers of environmental contamination.

Determinations of Territory Sizes Using Radio Tracking

Radio-location telemetry has proven to be widely applicable to the study of birds of prey in the field (Dunstan, 1970; Dunstan, 1972; Southern, 1964; Southern, 1965; Nicholls and Warner, 1972; Cochran, 1972; and many projects now in progress). Radio tracking could be used for three separate projects: 1) determination of territory sizes during nesting, 2) determination of sizes of winter hunting territories, and 3) postfledging followup of young birds. The potential for telemetry studies at Hanford is very high due to the accessibility and openness of the terrain. All of the above determinations would be useful in studying the foraging habits of raptors in reference to radioactive waste management.

Since the country is open and accessible, the specifications of the transmitters needed could be quite broad. Battery life of 4 weeks would be adequate. Use of a pulsed signal with a current drain of about 0.4 milliamps should prolong battery life far beyond 4 weeks. Designs for such transmitters, giving a range of 8 to 10 miles (more than adequate for the study area), are readily available. Dependable transmitters are also available for purchase (AVM Instrument Company, Champagne, I11inois).

Several birds should be tagged during the nesting season each year of the study, including, at least, prairie falcons, red-tailed hawks, Swainson's Hawks and great horned owls. Only a few days should be required to determine the home or winter range peripheries of each bird. The mobility provided by roads and other trails on the study area should permit contact with birds almost on demand. 
Determinations of territory sizes for both nesting and wintering birds, when correlated with population information should allow more accurate evaluation of the potential of the area for management. Considerations of actual and potential densities (both crude and ecological) should be possible. Radio tracking would also yield information concerning the postfledging period of young birds. This is a little studied portion of the raptor life history, during which considerable mortality is suspected to occur.

\section{Banding and Color Marking}

Historical occupancy of nests and survival of specific adults at nests are important indicators of the longevity of birds. To study survival of young and adults, as many birds as possible should be color marked on the study area. This work must be coordinated with the banding program of the U.S. Bureau of Sport Fisheries and Wildlife. The color-marking scheme should be advertised in regional and national ornithological journals. Useful information should feed back from federal band returns, observations and recaptures on the study area, and from amateur and professional ornithologists throughout the ranges of the birds. Knowledge gained about migration patterns, territory, dispersal and turnover within the populations to be studied, as can be determined from banding and color-marking studies, is worth the extra time and effort to mark the birds.

Predator-Prey Relationships

Simultaneous monitoring of both predator and prey populations has rarely been attempted in the past, although where this has been done, particularly on a long-term basis, significant results have been obtained (Hagen, 1969; Korschgen and Stuart, 1972). On a short-term basis, the research team at Rochester, Alberta, has been able to describe rates of exploitation of certain prey species by red-tailed hawks and great horned owls (Luttich, Rusch, Meslow and Keith, 1970; Luttich, Keith and Stephanson, 1971; Rusch, Meslow, Doerr and Keith, 1972). Other papers which deal with the role of birds of prey as predators (using data on both raptor and prey populations) include Brown and Watson (1964), Craighead and Craighead (1956), Hamerstrom (1969) and Lack (1966). In several cases, a response of raptor 
populations to changing prey densities has been shown, but the theoretical aspects of these responses need further development.

It is this type of study which must form the basis for further understanding of predator-prey relationships. Such analyses for several grassland species could be developed along the following line of reasoning. a) There is a determinable number of individual adults of each raptorial species per unit area at any given time (01endorff, 1973). b) These birds utilize food equal to a certain percentage of their body weight per day (Brown and Amadon, 1968; Craighead and Craighead, 1956; Marti, 1970). c) The adults produce a certain number of young each year (01endorff, 1973). d) A quantity of food (in grams) is required to produce a kilogram of hawk through 45 days of age (01endorff, 1971). e) This represents a quantity of food removed per unit area of territory size. f) From qualitative dietary information (01endorff, 1973; Smith and Murphy, 1973; Marti, 1970; data to be collected) for grassland raptors, the number of each prey species taken per unit area can be calculated. g) Comparisons of these numbers with quantitative prey population data available for the area will show the effects of birds of prey on their prey species (or vice versa). Much useful information for the final stage of the analysis outlined above will come from past and future Battelle studies on the Hanford Reservation. The results of the research will be magnified by comparisons between areas with low, moderate and high populations of raptors. No one is currently pursuing this indirect, but quite accurate, assessment of the effect of predatory birds on their prey resources. Furthermore, all of the data can be converted to appropriate energetic quantities for use in the general grassland ecosystem analysis being conducted by the International Biological Program.

Considerable background information on bird and mammal populations of the arid west is available through the International Biological Program, although that information is primarily directed toward solving range management problems as opposed to comparing vastly different natural habitats (e.g., around cliffs, creek bottoms and cultivated fields). During the study herein proposed, raptor and prey population levels would be assessed 
BNWL -1790

(simultaneously) for a number of habitats. Prime study areas at Hanford include the Wye Barricade, Army Loop Road, 200-Area, and Hanford and White Bluffs Townsites Regions. During the suggested study, prey population levels should be determined with techniques used by IBP mammalogists and ornithologists (Swift and French, 1972), with local variations used at the ALE Site (0'Farre11, Hedlund, Gies and Gilbert, 1972).

\section{Direct Predator-Prey Interactions}

The only other data needed to calculate rates of exploitation of prey species by predatory birds is an analysis of raptor food habits. One must know what prey species are being used, and to what extent, in order to evaluate 1) the effect of each predator on each prey species, 2) the collective effect of all predators on a single prey species, and 3) the collecttive effect of all predators on all prey species.

Food habits are most easily analyzed during the nesting season. Data should be collected during routine visits to nests by recording prey items brought to the nests. Additional food consumption data could be obtained through observations of kills and birds eating carrion, and analyses of pellets of indigestible material regurgitated by the raptors.

\section{Analysis of Data}

Data on raptor population dynamics, prey population levels, predatorprey relationships, abiotic factors and other pertinent data will be synthesized to define the major limiting factors of raptor populations on the Hanford Reservation. The results would be pioneering and innovative, since they would involve analyses of limiting factors of raptor populations using an adequate amount of quantitative data. Studies to date simply speculate about these factors.

In addition to shedding light on the "three-cornered argument on population theory" there are two bonuses of the proposed study. First, one could do further research, mainly involving artificial nest sites, to experimentally prove that nest sites are (or are not) limiting. If artificial sites are adopted, availability of nest sites, not prey, is limiting. This 
would be expected a priori in many areas of the arid west. If the artificial sites are not adopted, prey availability would be more suspect as a limiting factor. Second, the analys is of limiting factors can be exploited in management and conservation programs for raptors. Management (and the positive ecological publicity which would follow) have been discussed in an earlier section of this report. 
BNWL-1790

\section{LITERATURE CITED}

Andrewartha, H. G. 1961. Introduction to the Study of Animal Populations. University of Chicago Press, Chicago. $281 \mathrm{pp}$.

Andrewartha, H. G., and L. C. Birch. 1954. The Distribution and Abundance of Animals. University of Chicago Press, Chicago. $782 \mathrm{pp}$.

Brown, L. H., and D. Amadon. 1968. Hawks, Eagles and Falcons of the World. McGraw-Hill Book Company, New York. 2 vols. 945 pp.

Brown, L. H., and A. Watson. 1964. The golden eagle in relation to its food supply. Ibis 106:78-100.

Cade, T. J. 1971. Survival of the peregrine falcon: protection or management? Raptor Res. News 5:83-87.

Cochran, W. W. 1972. A few days of the fall migration of a sharp-skinned hawk. Hawk Chalk 11:39-44.

Craighead, J. J., and F. C. Craighead. 1956. Hawks, Owls and Wildlife. Stackpole, Harrisburg, Pa. $443 \mathrm{pp}$.

Dunstan, T. C. (ed.). 1970. Raptor Research Foundation continental osprey status survey--1969. Raptor Res. News 4(3):81-103.

Dunstan, T. C. 1972. Radio-tagging falconiform and strigiform birds. Raptor Res. 6:93-102.

Hagen, Y. 1969. Norske undersokelser over avdomproduksjonen hos rovfugler og ugler sett $i$ relasjon til smasnagerbestandens vekslinger. Fauna $22: 73-126$.

Hamerstrom, Frances. 1969. A harrier population study. In: Peregrine Falcon Populations, Their Biology and Decline. J. J. Hickey (ed.). University of Wisconsin Press, Madison. pp. 367-383.

Hickey, J. J. (ed.). 1969. Peregrine Falcon Populations, Their Biology and Decline. University of Wisconsin Press, Madison. $596 \mathrm{pp}$.

Korschgen, L. J., and H. B. Stuart. 1972. Twenty years of avian predatorsmal1 mammal relationships in Missouri. J. Wildlife Manage. 36:269-282.

Lack, D. 1954. The Natural Regulation of Animal Numbers. Oxford University Press, New York.

Lack, D. 1966. Population Studies of Birds. Clarendon Press, London. $341 \mathrm{pp}$. 
BNWL-1790

Luttich, S. N., L. B. Keith, and J. D. Stephenson. 1971. Population dynamics of the red-tailed hawk (Buteo jamaicensis) at Rochester, Alberta. Auk 88:75-87.

Luttich, S. N., D. H. Rusch, E. C. Meslow, and L. B. Keith. 1970. Ecology of red-tailed hawk predation in Alberta. Ecology 51:190-203.

Marti, C. D. 1970. Feeding ecology of four sympatric owls in Colorado. Ph.D. Dissertation. Colorado State University. Fort Collins, Colorado. $106 \mathrm{pp}$.

Nelson, M. W. 1969a. Status of the peregrine falcon in the northwest. In: Peregrine Falcon Populations, Their Biology and Decline.

J. J. Hickey (ed.). University of Wisconsin Press, Madison. pp. 61-72.

Nelson, M. W. 1969b. Research needs in reestablishing local raptorial bird populations. In: Peregrine Falcon Populations, Their Biology and Decline. J. J. Hickey (ed.). University of Wisconsin Press, Madison. pp. 403-407.

Nicholls, T. H., and D. W. Warner. 1972. Barred ow 1 habitat use as determined by radiotelemetry. J. Wildlife Manage. 36:213-224.

Nicholson, A. J. 1933. The balance of animal populations. J. Anim. Ecol. $2: 132-178$.

Odum, E. P. 1971. Fundamentals of Ecology. W. B. Saunders Company, Philadelphia. $574 \mathrm{pp}$.

0'Farre11, T. P., J. D. Hedlund, R. A. Gies, R. J. 01son, and R. 0. Gilbert. 1972. Smal1 mammal studies on the ALE Reserve, 1971. U.S. IBP Grassland Biome Tech. Rep. No. 174. $32 \mathrm{pp}$.

0lendorff, R. R. 1971. Morphological aspects of growth of three species of hawks. Ph.D. Dissertation. Colorado State University. Fort Collins, Colorado. $460 \mathrm{pp}$.

0lendorff, R. R. 1972. The large birds of prey of the Pawnee National Grassland: nesting habits and productivity. U.S. IBP Grassland Biome Tech. Rep. No. 151. 59 pp.

0lendorff, R. R. 1973. Ecology of the nesting birds of prey of northeastern Colorado. U.S. IBP Grassland Biome Tech. Rep. No. 211. $233 \mathrm{pp}$.

Rusch, D. H., E. C. Meslow, P. D. Doerr, and L. B. Keith. 1972. Response of great horned owl populations to changing prey densities. J. Wildlife Manage. 36:282-296. 
Smith, D. G., and J. R. Murphy. 1973. Breeding ecology of raptors in the eastern Great Basin of Utah. Brigham Young Univ. Sci. Bull., Biol. Ser. 18(3):1-76.

Southern, W. E. 1964. Additional observations on winter bald eagle populations: including remarks on biotelemetry techniques and immature plumages. Wilson Bu11. 76:121-137.

Southern, W. E. 1965. Biotelemetry: a new technique for wildlife research. Living Bird 4:45-58.

Swift, D. M., and N. R. French. 1972. Basic field data collection procedures for the grassland biome 1972 season. U.S. IBP Grassland Biome Tech. Rep. No. $145.86 \mathrm{pp}$.

Wyrne-Edwards, V. C. 1962. Animal Dispersion in Relation to Social Behavior. Hafner, New York. 
BNWL-1790

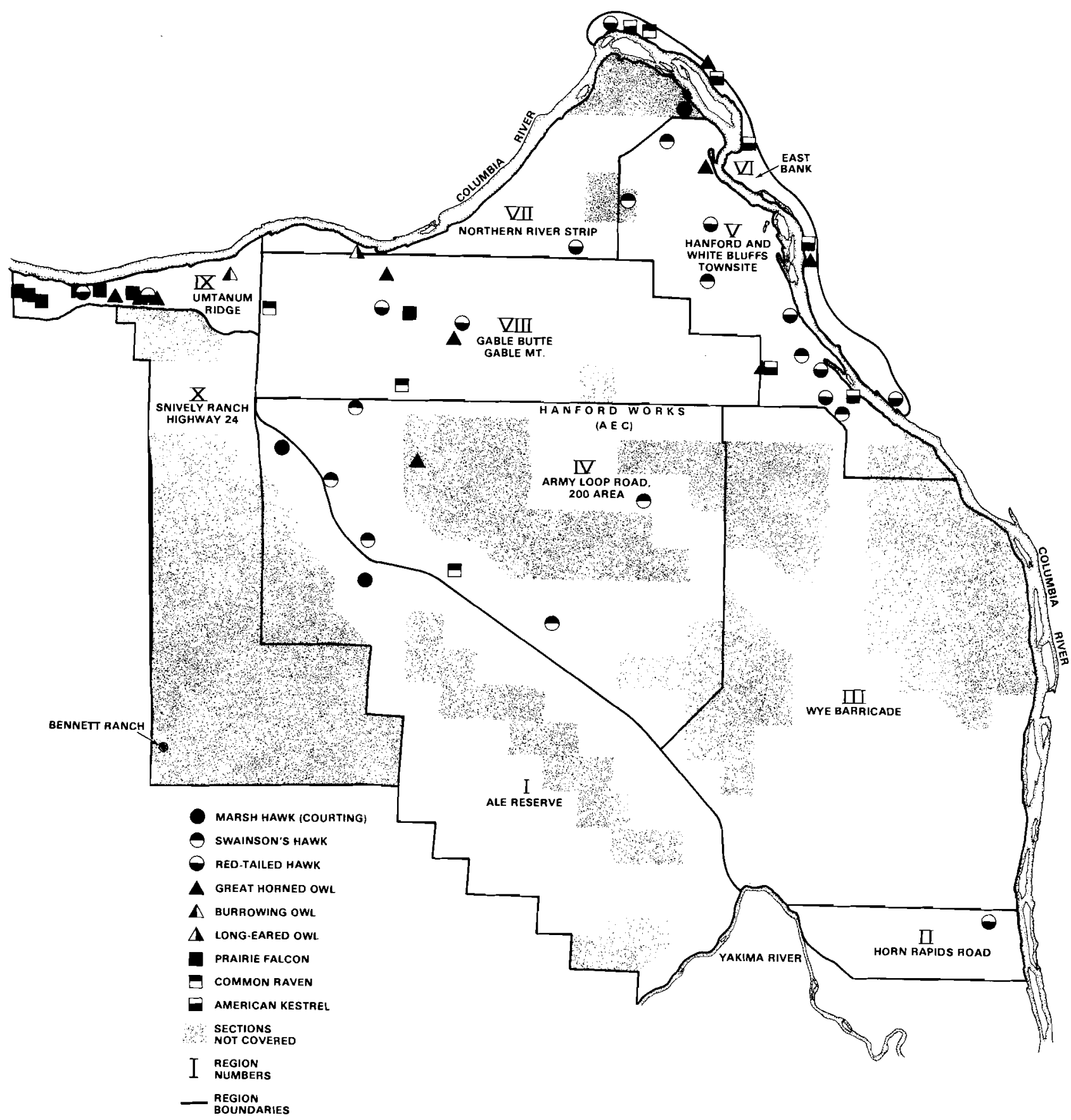

FIGURE 1. Map of the U.S. Atomic Energy Commission's Hanford Reservation Showing Locations Where Raptorial Birds Were Observed During February-May, 1973. Region boundaries and numbers arbitrarily assigned during this study are shown with unsurveyed regions clearly indicated. Descriptions of the regions can be found in the text. 


\section{$\underline{\text { DISTRIBUTION }}$}

No. of
Copies
$\frac{\text { OFFSITE }}{1}$ AEC Chicago Patent Attorney

A. A. Churm

4 Division of Biomedical and Environmental Research

J. L. Liverman

W. S. Osburn, Jr.

C. L. Osterberg

J. Swinebroad

200 AEC Technical Information Center

1 Argonne National Laboratory

J. Kline

1 Brookhaven National Laboratory

G. M. Woodwel 1

1 Los Alamos Scientific Laboratory

W. C. Hansen

1 Oak Ridge National Laboratory

S. I. Auerbach

1 U.S.A.E.C. Nevada Operational Office

P. B. Dunaway

100 Dr. Richard R. Olendorff

1939 Wyoming Street

Bremerton, WA 98310
No. of

Copies

ONSITE

1 AEC/RL Patent Attorney

R. M. Poteat

2 AEC Richland Operations Office

P. F. X. Dunigan

B. J. Melton

104 Battelle-Northwest

E. L. Alpen

W. J. Bair

C. D. Becker

J. H. Bender

G. M. Dalen

M. J. Duever

L. L. Eberhardt

J. J. Fuquay

J. D. Hedl und

F. P. Hungate

T. P. O'Farrel1

K. R. Price

W. H. Richard

L. E. Rogers

W. L. Templeton

J. M. Thorp

B. E. Vaughan (50)

D. G. Watson

W. A. Watts

R. E. Wildung

Biology Library (3)

Technical Information (5)

Technical Publications (3) 